\title{
The Inland Revenue: a statutory ostrich?
}

\author{
by John Booth
}

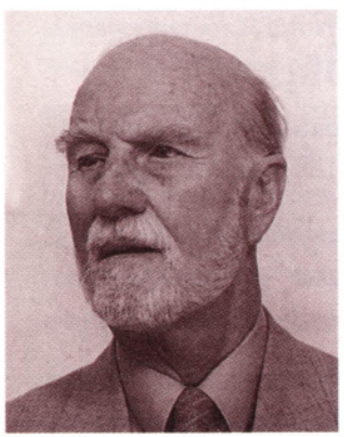

In this article on the Inland Revenue, John Booth highlights problems which he considers can be attributed to a lack of statutory accountability for the Revenue Service to Parliament.

John Booth

$\mathrm{T}$ he authority and direction over the Inland Revenue by HM Treasury was discussed by the writer in European Financial Services Law ((1999) 6 EFSL 1) who concluded that there was inadequate accountability to Parliament, by the Treasury, for the Revenue and that this should be re-defined by statute.

This article shows that similar failures of statutory accountability exist for the Revenue to Parliament, and that, additionally, the Revenue did not exercise the statutory 'care' in its management of inland revenues, (Inland Revenue Board Act 1849 , s. 1) until 'caring for staff' was introduced in 1991 (Cmnd 2086 at 1-3). The present failings of the Revenue over the introduction and administration of the self-assessing programme are shown to be from the consequences of many years of administrative failures for which no annual procedure of accountability to the House of Commons exists.

\section{SELF ASSESSMENT: THE DELUSION}

The delusion is from the assumption that self assessing was derived from the Inland Revenue Development Plan (IR, January 1993), whereas its origins were in the administrative failures recorded in the reports on the Revenue by House of Commons committees from 1968 to 1969. Seventeen reports of the Estimates Committee (1968-69 HC 101 I - xvii) noted then the serious situation for the Department, but that it was:

'... more serious for the public [where] errors and delays [caused] widespread distress and hardship with no legal right of redress.'

It was a department in turmoil from impossible budgetary demands, staff resignations, avalanches of paper, and the inspectorate 'in splendid isolation', with the administration at breaking point. Eleven subsequent House of Commons reports from 1979-80 to 1992-1993 revealed that the crisis was never resolved (see the writer's review of this period in Stand and
Deliver! The Inland Revenue and Non-Statutory Taxation, ISBN 1872 879694 , chap. I and II), and continues to date.

That period of crisis peaked in October 1985, when unanswered letters over 14 days old had reached in excess of 6 million, over 240 inspectors had resigned in that year, and staff complement had been reduced by some 15,000 , as the following graphs show:
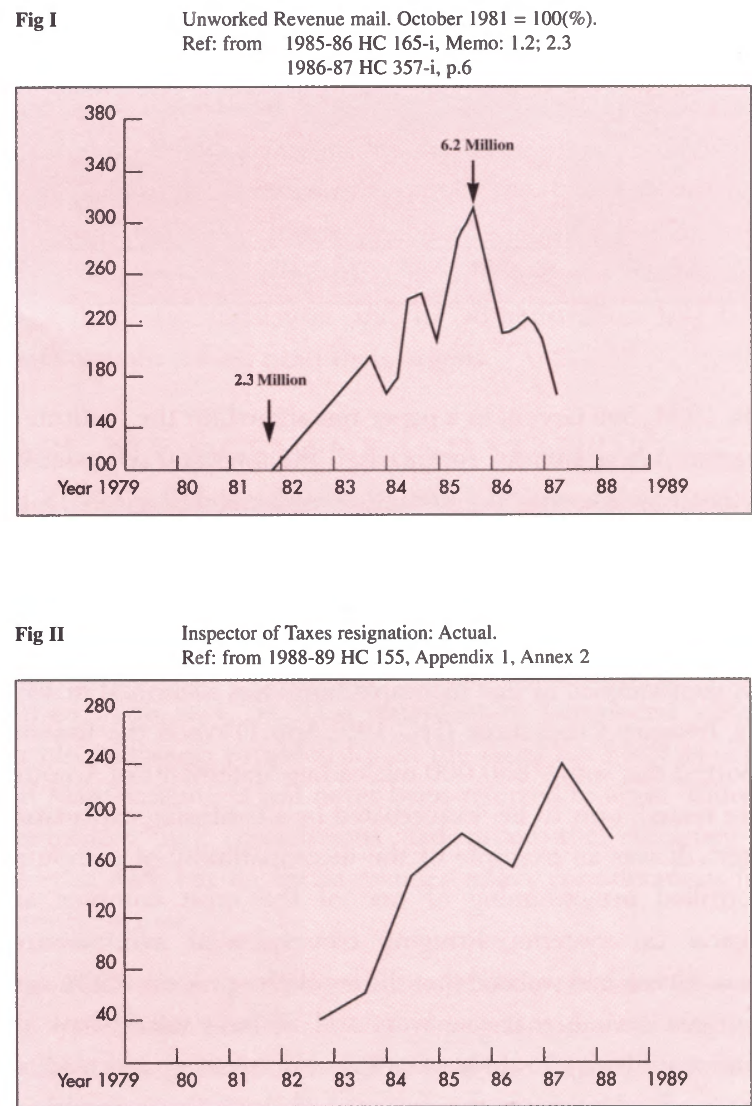
The real reason for self-assessing was identified when the Committec of Public Accounts was told that the cause of the Revenue's crisis stemmed from the government's policy to reduce the size of the Civil Service and that the Revenue staff would be reduced by 25 per cent (1984-85 HC 315 - iii, q. 45). The consequences are shown in Fig. III below.

The origin for this decision is that the then Prime Minister received a report from an 'Efficiency Unit' on 'Improving Management in Government', in 1988, about which the then Cabinet Secretary replied to a question from a Treasury and Civil Service Committee that it was:

.. not a White Paper to which the Government subscribed or takes responsibility [for] ... ' (1987-88 HC 370 - I, q. 49)

For the Revenue the answer would be to replace staff with computers and, by removing the management authority for an inspector to 'assess the tax' (Taxes Management Act 1970 ('TMA 1970'), s. 8), and making taxpayers liable to assess themselves to tax (Finance Act 1994, s. 179) the management crisis of reduced staff, resignations and paper mountains would be resolved. However it was a Revenue management provision; it was not in a budget statement, or the Finance Bill of 1994, but inserted in Committee from Revenue pressure and, although passed in the Finance Act 1994, had not received the scrutiny of the House of Commons.

Fig III Revenue Staff in post $(X=1000)$ Ref: from 1987-88 Cm 529, p.6; 1992 Cm 2086, p.7

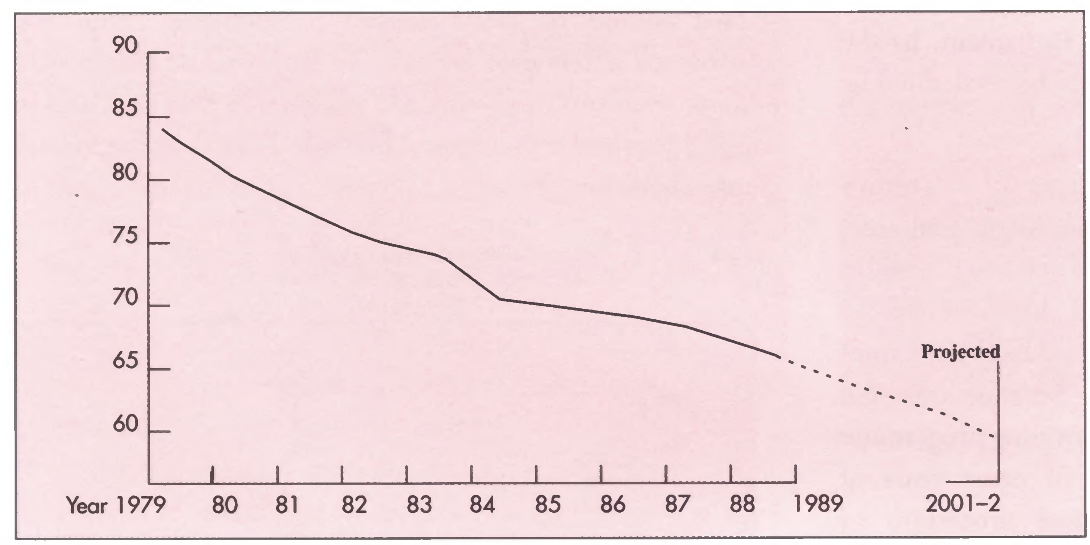

In 1994, Sue Green, in a paper researched for the Institute of Chartered Accountants, summarised the intended self assessing as 'incompatible with the present complex and illogical UK tax system' (Compliance Costs and Direct Taxation, ICA (1994) at 1).

\section{SELF ASSESSMENT: THE INCOMPATIBILITY}

A consequence of this incompatibility was identified in 1999 to a Treasury Committee (HC 199, App.1) when the Revenue reported that some '870,000 misleading Statements of Account' were issued, only to be 'exacerbated by a confusing explanatory letter'. It was an example of the incompatibility of computercontrolled programming of one of the most complex and illogical tax systems, bringing consequential administrative chaos. Green had warned that the legislative process was in need of urgent review, that taxpayers and advisers would have the greatest difficulty in understanding self assessing and that 'we cannot afford to ignore the potential chaos that may result'.
By 1995 the Financial Times had reported Revenue errors costing $1350 \mathrm{~m}$ and the Chartered Institute of Taxation was quoted as saying that:

'Taxpayers did not ask for a change and if it does not come in properly people will feel aggrieved.'

The 870,000 misleading statements confirm the administrative failures over which self-assessed taxpayers and their advisers are now justifiably aggrieved. All of which confirms Green's prescience that self assessing really is incompatible with the system of UK taxation. But the causes lie deep within the department's historic failings, added to by a government's denigration of civil servants from 1979, and reducing staffing complements.

\section{THE ACCOUNTABILITY PROBLEM}

Following criticisms of inadequate accountability by the Inland Revenue, the Treasury Committee (HC 199, op. cit.) said that:

'We have become convinced of the need for regular and systematic scrutiny of the Inland Revenue and the tax system by a departmental committee.'

Such a regular and permanent committee is long overdue, as previous examinations by Estimates, and Appropriation Committees, the Public Accounts Committee, and Treasury and Civil Service Committees, in 1937, 1961, 1981, 1986 and now 1999, have consistently recommended. Finally the government's response to the Sixth Special Report is encouraging in that it was:

happy to co-operate fully with any further inquiries into the Inland Revenue and the tax system.' (1998-99 HC 746 at iii)

In 1971 a similar recommendation from the Select Committee on Procedure had been blocked by the then Permanent Secretary to the Treasury (1970-71 HC 276, XXII, 655, para. 43(4)). However, in 1999, the Paymaster General dismissed the proposal for a Royal Commission, claiming that scrutiny of the tax system was provided in the Finance Bill, ignoring that the self assessing proposals had never appeared in a Finance Bill, and stating that:

'I cannot immediately see the attraction of having a Royal commission. It is the job of governments to do this and be held to account for it.' (HC 199 q. 392)

This was despite the submission by the Chartered Institute of Taxation, and others, that 'the time is ripe for a Royal Commission on Taxation' in support of its Memorandum to the Treasury Committee (HC 199, op cit p.26). Later evidence is quoted to show that both the Treasury and the Revenue had plotted to pre-empt the 1951 Royal Commission, with a department report on taxation. It is therefore quite vital that commissions on taxation should be open and quite independent of government, the Treasury and the Inland Revenue.

There is still the question of accountability in regard to the use of contracted-out computer services and self assessing. In 1987 the Committee of Public Accounts and the National Audit 
Office had raised the question of the control of Information Technology in the Revenue (HC 132 and 262), which the Revenue claimed to be under the Taxes Management Act 1970, s. 1 and the Revenue Regulation Act 1890, s.1. However, in 1992 the oversight was questioned by the Select Committee on the Parliamentary Commissioner (the Ombudsman) (HC 158, q. 40-47), when it was denied that there was any detraction from the jurisdiction of the Ombudsman, who is excluded from investigating commercial transactions. The Revenue claimed in a letter of 24 September 1993 that:

' ... access provision would be included in [the] contract ...'

A press release added that the procurement would be as for Revenue employees under the unauthorised disclosures of taxpayer personal information (23 November 1993), under the Finance Act 1989, s. 182. However the Board was disingenuous in these responses because s. 182 is in consequence of the Official Secrets Act Order (SI 1990/199), with prosecution only initiated by the Board (1990/199)or the Director of Public Prosecutions. This means that an investigation of procurement contracts, by the Ombudsman, is circumvented, and this oversight has not been resolved.

A Deputy Chairman of the Board in a speech on 18 May 1993 to the Tax Faculty of the ICA acknowledged the question of accountability by the Board to the Public Accounts Committee. In this speech it was stated that the new Inland Revenue was 'based on the sound foundations built by the people of yesterday'

But how sound are these foundations?

\section{SOUND FOUNDATIONS WITHOUT CODIFICATION?}

From 1849 the Revenue has mishandled its administration. Although created by the Revenue Board Act of February 1849, without statutory provision for any reports to be made, a Treasury Minute had requested 'a Report to My Lords from time to time' (PRO T 29/529, 12 January 1849). This minute was ignored. A second direction was issued in 1856 for the 'calendar year ending on the 31 December', which admonished the Board, regretting that:

'... such a custom has not been called into existence at an earlier period ...' (PRO T 22/36, 27 November 1856)

The first Report, without apology or reason, was made on 16 February 1857, for the 'year ended 31 March 1856' (1857 Sess 1 [2199], IV, 670) which ignored the requested calendar year, causing confusion in later reports between 5 April and 31 December. However, the blatant administrative blunder is that no reports were ever made, or exist, for the period February 1849 to 31 March 1855. During this time a Chancellor projected the cessation of income tax (Taxes Act 1853, s. 1), and the Crimean War began, which forced the continuation of income tax. No Treasury or Revenue reports exist for either of these momentous events, or of the funds raised to prosecute the war.

A Select Committee reported the Minutes of Evidence on his first Report to the House in 1862 (HC 370 VII, 131) but Disraeli rejected any discussion. Subsequent challenges, in the House, by Select Committee Members, in regard to criticisms of the Revenue raised in the Report were also dismissed by Disraeli as an 'inconvenience inherent in the nature of the tax' (165 Hansard 3s 1862 cols. 122-7). It was of course nothing of the sort as it could have been amended by legislation, for which the Chancellor (Disraeli) had responsibility.

These Minutes recorded the unfavourable feeling of the public towards the Inland Revenue and the 'opinion that this feeling is well-founded' which was later endorsed in Green's Report in 1994.

In 1897 the Committee of Public Accounts (HC 196, VIII, 5) was dissatisfied with the Revenue's accounts, and the 1906 Select Committee (HC 365-IND, IX, 290) called for a codification of tax laws. Finally, the 1920 Royal Commission (Cnund 615) called for a codification of all decisions of tax principles and interpretation, effectively the abolition of the existing tax legislation. But it was the prescience of the then Winston Churchill, in 1927, as Chancellor, who wrote the Minute which created the Income Tax Codification Committee, meeting all of the recommendations of the 1920 Royal Commission.

After nine years of dogged determination this Committee produced the impossible in 1936, a Report (Connd 5131) and a Finance Bill (Cmnd 5132). The Report was devastating. It referred to the 'chaotic condition' of existing legislation, its 'haphazard process of amendment' as an 'incoherent accumulation' and recommended total 're-codification at short intervals to prevent a relapse into the existing state of confusion'. It remains a complete rebuttal of any suggestion of the 'sound foundations' too easily claimed in 1994. No codification took place, and the political prevarication in response to the nine questions raised in the House between 1935-36 and 1938-39 (see Stand and Deliver!, op cit at p.1) remains incomprehensible. However, it was revealed in 1955 by the last Royal Commission (Cmnd 9474, para. 1077-80) that the opposition had come from the Revenue on the grounds of it not being 'a viable instrument'. Later, in 1993, a Secret Revenue file on the 1927 Committee, marked 'closed to year 2006', was discovered (PRO IR 40/3654, T 1135/13/30), which may yet reveal reasons for the administrative opposition to successive tax reforming reports. The Commission paid tribute to the 'very highly qualified Committee which had prepared a draft codifying Bill'. All of which confirms that, in 1955, both tax legislation and its administration had been fundamentally flawed from their origins.

\section{CARE, MANAGEMENT AND STAFFING}

In 1992, under pressure from White Papers on the citizen's charter and Competing for Quality, the Revenue, in its Annual Report, decided to improve the 'customer services, compliance and cost efficiency', but also, to impress its staff as a 'good employer', added that 'caring for Staff has an equal priority' (Cmnd 2086 at 1, 3). This statement re-introduced 'caring' because, although provided for in the Board Act 1849 as 'Care and Management', it had never been referred to again. Indeed, committees and commissions had noted the efficiency of Revenue staff, but the recommended salary considerations had never been met.

In 1999 the Treasury committee considered 'Care for staff' and noted the need for a well-managed and motivated staff confident in the aims and objectives of the Department. But it also noted a 1998 Staff Survey, which suggested that: 
the Revenue is still facing many of the same issues it identified in $1992 \ldots$,

Also, in measuring sickness absences as an indicator of staff problems, showed that this had risen from 9.6 days per calendar year per staff member in 1994 to 11.7 in 1997 (HC 199 para. 21). This endorsed the view of the 28 adverse Reports on the Revenue from 1968 to 1993 of a permanently disillusioned staff of low morale. In 1994 the Revenue admitted that 'Morale is not as good as it has been' (HC 532 - i, q. 103). In 1985 it was shown to have been bad, but endorses an inspector's view in 1999 that 'Morale is [still] a very serious issue' (private source).

The story is bleak in regard to the inspectorate. In 1961 an Estimates Committee reported the inspectorate as 300 below its authorised strength (HC 245, VI, 1). In 1968 the graduate recruitment showed a wastage of 50 per cent (HC 101 - vii, XII, 09, and HC 474, XIII), which has never been stopped. In 1986 a Treasury and Civil Service committee reported that trained inspector resignations were 1.8 per cent in 1982-83 and 7.1 per cent in 1985-86 (see Fig. II).

The rigorous training programme for inspectors had some shortcomings. In 1977 RT Bartlett had written in complimentary terms of the programme for inspectors ('Inland Revenue Training for the Inspectorate', [1978] BTR 289). However Bartlett noted:

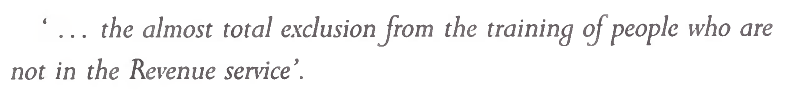

An introspection not conducive to a broad consideration of affairs. Additionally the three-year course required six to seven years to complete for some 40 per cent of trainees. No other independent review is noted, and in 1992 the Revenue proposed that all staff would be in a single staff group (Cm 2086). There was no reference as to how the different grades in the single group would be trained in future, but the abolition of the statutory duties of the inspector (Finance Act 1994, s. 179) is noted as a management policy.

Elitism has therefore been removed from the inspectorate but, in view of the self-assessing disasters, have the trained skills gone? The latest Committee reports do not indicate that new computer training programmed has been linked with the new management changes to the increasing complexity of tax legislation. Neither has elitism gone from the Board.

The fault line in regard to the Board still stems from the criticisms in the Fulton Report (1968, Cmnd 3638) of the administrative service with 'too few skilled managers'. By 1994 it was noted that the 'cult of the generalist' was 'obsolete' and that the senior civil service was too insular; it mirrored the findings of the 1968-69 Estimates Sub-Committee (HC 101, XIII, 517).

In 1968 the Sub-Committee was not impressed that the Chief Inspector of Taxes was (and is still) not a member of the Board, that the Board only met informally, conducting business orally and that the members had no formal training in taxation. In 1992 two non-revenue members were invited onto the Board in a non-executive capacity (Cm 2086) there was no public advertisement for the posts and another management tier was interposed between the Board, heads of department, staff and the public, ensuring the exclusivity of the former. Finally, in 1994, a Support division was created (Inland Revenue letter, 15
February 1994), which replied to all questions directed at the Board, now in glorious isolation.

\section{REFORMS AND OBSTRUCTIONS}

Whilst the Board is charged that taxes shall be under the 'care and management of the commissioners' (TMA 1970, s. 1), the consequences of legislative demands and administrative failures precipitated the rush to self assessment, with the acceptance that the statutory responsibility of 'collection and management of inland revenue' (IRRA 1890, s.1) was unattainable. The 28 quoted adverse reports on the Revenue from 1968-69, under such headings as 'Tax Office Delays', 'Arrears of Work', 'Manpower Losses' and 'Getting tax right first time', all reflect the Revenue's inability to recruit, train and retain sufficient staff to meet their statutory requirement to 'collect and manage inland revenue' with a permanently undermanned and undertrained staff.

In 1936 the failure to meet the requirement of the Report of the Codification Committee for greater simplicity, and to codify precedents, has permanently scarred all subsequent attempts at reform. The 1996 attempt to 'Re-write tax legislation in plain English' (press release, 2 July 1996) cannot succeed because, as Sir John Donaldson, MR explained in 1984, that:

'It is for Parliament to make the laws and for the courts to tell the nation, including members of both Houses of Parliament, what those laws mean.' (R ${ }_{v}$ HM Treasury ex p. Smedley [1984] 1 All ER 589 at 593)

Legislation cannot therefore be 're-written' or 're-drafted', and it ill behoves the Revenue to suggest that it can. The Revenue do introduce their own interpretations of tax law through pamphlets and 'Tax Bulletins', but all are inadmissible before the courts and reflect the Revenue's interests, when the taxpayer may defend his/her own interests through independent advisers.

More serious however is when the Treasury and the Revenue seek to influence reforming proposals. In 1949 a top secret 'Exercise Diogenes' was set up to change taxing policies. It was to be 'kept within a small circle' as the exercise was 'without Ministerial direction' (PRO IR 40/12845, BC(D)(49) 1, 22 July 1949). In 1950 this research re-emerged to pre-empt the 1951 Royal Commission on Taxation by suggesting practicable schemes:

\section{'... or you leave the field open to the cranks and ignoramuses.'}

When these schemes were discovered by the Chancellor the Revenue were told that:

'I do not think they should put forward a scheme at all.'

In 1978 the Meade Report suffered from a similar isolating treatment despite the high ethical objective to: 'command a wide consensus of political approval' in order to set 'an acceptable floor to the standard of living of all citizens' (The Structure and Reform of direct Taxation', IFS 91978)) It also considered the 'harmonisation of taxation policies with other EEC countries'. No other budget or commission has set such a high political standard, but the Revenue's only response was that:

'The pursuit of equity and simplicity usually leads in opposite directions. Where equity almost always prevails - at the cost of simplicity.' (1978 Cnd 7473, Ch.V) 
It was the expected negative response from a department set on isolating 'cranks and ignoramuses'.

Finally, in regard to the tax re-write proposals, the Chartered Institute of Taxation's memorandum to the 1999 Treasury Committee noted that the terms of reference precluded any change in the law, was 'forced to re-incorporate out-dated concepts' and that 'an opportunity [was] being lost to consider amendments of substance which would simplify the tax system'. (HC 199. Memorandum para. 5.2)

But, as the Revenue had deftly dealt with the reforming opportunities in 1936 and 1978, the possibilities of reform and comprehensible tax legislation are as remote as ever.

\section{COMPLAINTS}

The Revenue's response to proved complaints is a minimum acceptance of responsibility and reluctance, despite the Taxpayer's Charters and the Codes of Practice, Mistakes by the Inland Revenue, to compensate for the cost of a taxpayer's compliance with the laws.

Historically the Revenue and the governments have rejected any responsibility for tax legislation. However, Members' complaints in the House, from the first Report by the Revenue, brought a reply from Gladstone that:

'The amounts of tax payable is intrusted to the Commissioners, and there is no appeal.' (165 Hansard 3s 1862, cols. 122-7)

DW Williams showed that Parliament had no control over taxation and quoted Harcourt in 1892 that:

'Income tax questions are not in the hands of the Government, but under the control of the IT Commissioners.'

This practice continued until 1950, when a chancellor refused to reply to a tax question (A Mere Matter of Machinery, DW Williams, LL.M, Bristol University, 1975). Thereafter, MPs, as the taxpayers' watchdog, took up complaint questions with the department until the Parliamentary Commissioner Act 1967 provided the countervailing power against an obdurate department, which would now have to face a:

'written complaint to a member of the House of Commons [on the grounds of] injustice from maladministration.' (s. 5(1)(a))

From the outset maladministration was defined as: 'bias, neglect, inattention, delay, incompetence, ineptitude, perversity, turpitude, arbitrariness, and so on' (734 HC Deb 5s 1966-67 cols. 42-43. The Revenue has tried to minimise these criteria under the headings of 'Mistakes', 'Delays' and 'Serious or persistent errors' (Code of Practice 1). But a complaint to an MP for the Ombudsman should include the parliamentary definitions. A Select Committee was also ordered in November 1967 'to examine reports laid before this House by the Parliamentary Commissioner for Administration' (HC 258 XIV 289). A consequence was that, for the first time, complaints against the Revenue could at last be brought to the floor of the House. But an immediate problem was to force the Revenue $t$ pay the compensation authorised by the Treasury Minute of 31 December 1897 on grounds of 'equity or compassion'. In 1969 the Revenue were shown to have claimed that an apology 'is sufficient remedy for maladministration' (HC 385, XIV, 383).

Others did not think so and in 1974 the Revenue were persisting in refusing to recompense claimants' costs in rebutting false allegations. The Chairman of the Select committee told the Revenue to look at the matter again as 'we are all rather disturbed about this matter' (HC 454, XXX, 1, q. 49-50). The Revenue did and finally agreed to pay the compensation in a letter of the 16 June 1975 (1974-75 Cmnd 6144 , para. 4). However the letter was not published to tax districts and was not discovered by the writer until 1992, but was finally acknowledged in 1994 in the Code of Practice 1, with the words 'You may be able to claim back your expenses.' However, in 1999, compensation from a successful claim to the Adjudicator is still being resisted in regard to a taxpayer's compliance costs.

Complaints against the Revenue escalated to a peak in 1979 , and widespread grievances by taxpayers required a simpler and easier access for a complainant. In consequence a Revenue Adjudicator was appointed to act as an 'impartial referec where people feel they have been badly treated by the Revenue' (press release, 17 February 1993). It was fully justified, as the Adjudicator received 2581 complaints in the first year to 31 March 1995, compared to the Ombudsman's 85 in 1967, from a more articulate public.

However, complainants to the Ombudsman or Adjudicator both require a tenacity of purpose with a motivation to succeed in order to overcome the Revenue's procedural obstacles to the officer in charge of a district, and then to the Regional Controller. One district's excuse for delaying a claim was that it 'would open a floodgate' of other claims, the justification of the claim was ignored. Other claims require months of firm responses tot he Revenue's blandishments before reaching either goal. But the advantage of the Adjudicator is the simpler criterion of having been 'badly treated by the Revenue' and not having to prove 'injustice through maladministration' to the Ombudsman. A claim can also be made, after the Adjudicator's findings, to the Ombudsman, if injustice has been proved. In both cases compensation for the costs of compliance with the tax laws can be made.

A more recent and extreme case of a complainant was proved by the findings of a Special Commissioner's decision in 1996 that a district inspector had 'wished to get his own back on the taxpayer's accountant who had complained' and that 'the Revenue had acted wholly unreasonably in connection with the hearing, having shown bad faith' ( $S p C$ Scott \& Anor v McDonald [1996] STC (SCD) 381). With substantial compensation this was a salutary outcome and endorses the view that the Revenue simply do not meet the criteria that the collection of revenues is being managed with 'care', as required by statute, and with conviction.

\section{CONCLUSION}

The writer has portrayed a bleak taxation record from the Board's creation in 1849 , but with present taxing statutes originating in the 1803, 1842 and 1853 Taxing Acts, still without codification, another analysis in 1999 is impossible. The evidence provided for earlier Parliamentary Committees and Commissions was a vital analytic tool.

The present day Revenue's annual reports are disappointing. In 1962 Professor RM Titmus noted that the Board's comprehensive statistics ceased after 1918 and that, without criteria for deciding the unit of taxation for the family or individual, were of little further value (Income Distribution and 
Social Change, Unwin University Books, p. 67). Today the transient hydra of Treasury commissioners, responsible for the direction of the Revenue, but without formal meetings recording decisions, and no harmony between First Lords of the Treasury and Chancellors, have little possibility of forming cohesive taxation policies. Into this political vacuum the Revenue have injected their own policies, but - as with the issues raised of accountability, caring, codification, management and reforms - without direction, have not been able to meet those high standards which taxpayers have a right to expect.

In $1861 \mathrm{JS}$ Mill wrote that the office of a 'representative assembly is to watch and control the government' (Representative
Government, ed RB McCallum, Basil Blackwell, (1949) at p. 172). This writer suggests that the greater need in modern times is to watch and control the Treasury. (c)

\section{Dr John Booth}

Fellow of SALS and former inspector of taxes

Dr Booth is the author of Stand and Deliver! The Inland Revenue and NonStatutory Taxation, Winchester, (1998) Waterside Press, ISBN 1872870 694; e-mail WATERSIDEPRESS@compuserve.com

\section{Announcement}

\section{A NEW SCHEME FOR THE INSTITUTE}

The University has recently ratified a new constitution for its School of Advanced Study, under which constituent institutes are required to revise their Schemes in accordance with a new model format. As a result the new Scheme of the Institute shows a number of significant changes from the previous version, the most important of which are as follows.

1. All institute Boards are to be re-named Advisory Councils, and their terms of reference revised, in order to more accurately reflect the advisory nature of their responsibilities. In practical terms, however, there will be little change as far as the Institute is concerned as its Board has operated on this basis since 1989, whereas in some other institutes Boards have hitherto tended to exercise quasi-managerial functions.

2. The Institute has inserted the new formulation of its objectives as recommended by the Report of the IALS Review Committee.

3. The University has required the size of the new Advisory Councils to be significantly reduced as the old Boards were seen as being too unwieldy to exercise the functions now required of them. As a result the total maximum membership of the Institute's Advisory Council is being reduced from 41 to 26 (inclusive of ex-officio appointments and co-opted members) although it has still been possible to retain representation from all the academic and professional constituencies served by the Institute. A reduction in membership was also a significant recommendation of the Report of the IALS Review Committee. At its November meeting, the Council agreed that all current appointments, except for that of the Chairman, would terminate, and the Council will be re-constituted according to the new provisions.

4. The new Scheme provides for revised arrangements for the appointment of the Director, in accordance with a new protocol applicable across the School, which gives a greater degree of discretion in the process to the Vice-Chancellor of the University.

5. The Institute has taken the opportunity of the revision of its Scheme to include its own provision for the appointment of a Deputy Chairman, and it is envisaged that the holder of this new post will also chair the Development and Advisory Committee. This dual role will be a crucial one during the next few years in the context of the Institute's fund raising initiatives.

The new Scheme of the Institute was discussed and approved by the Advisory Council at its November 1999 meeting and has now been forwarded to the Board of the School (as the Curators have been re-named) for formal ratification. Copies of the Scheme may be obtained from me.

\section{David Phillips}

